\title{
Gatekeeping for Survival: Evidence from Online News Portals in Ghana
}

\author{
Caroline Aboagye Da-Costa* Eric Opoku-Mensah (PhD) Daniel Machator \\ Ghana Institute of Journalism, $32^{\text {nd }}$ Gamel Abdul Nasser Road, Osu, P. O. Box GP 667, Accra - Ghana
}

\begin{abstract}
Media competitiveness and survival remain a huge responsibility in the digital era which is dictated by technological advancement, with its attendant content creators who publish what they deem as newsworthy. One approach to survival as identified in strategic media management literature is branding, which is portrayed by drawing a balance between journalistic and commercial orientations. Using the Media, Brands, Actors and Communication (MBAC) model and semi-structured interviews with online news editors, social media managers and social media curators of three solely online digital media brands in Ghana, this paper argues that the branding strategy and orientation of solely online news media portals in Ghana is more of commercial than journalistic as perceived in their type of gatekeeping. This is attributed to the need to remain competitive, sustain their small businesses and to survive. The study concludes that to remain relevant and sustainable, solely online news portals need to consider mergers as an option.
\end{abstract}

Keywords: brand identity; branding strategy; gatekeeping; Ghana; online news portals; survival

DOI: $10.7176 / \mathrm{NMMC} / 99-02$

Publication date:October $31^{\text {st }} 2021$

\section{Introduction}

The emergence of digital media opened up the gatekeeping function to everybody, resulting in a multiplicity of news streams (Bullard 2013, 3; Welbers \& Opgenhaffen 2018, 4731; Shoemaker \&Vos 2009). To alleviate the negative impact of digitization on their operations, most traditional news organisations have extended their operations by building online and digital brand extensions of their traditional media forms. Not only has this improved their survival potential, but has served as an opportunity to remain relevant to the different audience segments presented by the digital era (Aboagye Da-Costa, Ganaa \& Apeakoran 2021). This notwithstanding, some news organisations were born with the digital era because their formats are purely online without any traditional media affiliation. The survival of such purely online and digital news brands, especially in Ghana becomes a challenge because the media space is populated, highly competitive and they extensively depend on their online and social media presence as well as the engaging content they publish, which is a product of the kind of gatekeeping they engage in.

News media gatekeeping is not just a routine activity, but it defines the brand that a news organization stands for, through the choices and selection made by the anchors of the organization. News organisations combine both market-driven and journalistic-driven brand identities. While the market-driven agenda ensures the continuous survival of the media outlet in terms of financial inflows, the journalistic agenda burdens media outlets to inform their audiences with the sound journalistic information that is relevant, objective, authentic and credible. The balance drawn between these two objectives and the direction of emphasis often determine the branding orientation of the media outlet.

With the increase in news creators and distributors who publish anything they deem as newsworthy, the value of professional journalistic gatekeeping on online digital news media platforms become a subject for discussion and also worth investigating. This study delves into the gatekeeping procedures of three purposively sampled solely online digital news brands in Ghana to interrogate how their gatekeeping strategies influence their competitiveness and survival.

\section{Literature review}

The digital media era has opened up the gatekeeping function to everybody who has access to the internet and a network device (Bullard 2013, 3; Welbers \& Opgenhaffen 2018, 4731), resulting in a multiplicity of news streams. Aside public, citizens and online-users who are individuals involved in content creation and distribution, traditional media now has representation on online digital platforms, and there are also solely online digital news outlets and blogs. Media organisations are burdened with the need to stay relevant and survive in spite of intense audience-attention competition, competing products, converged technologies and audience fragmentation brought about by globalisation, digitisation of media and interactive technologies in the multichannel and digital era (Chan-Olmsted 2011; Chan-Olmsted \& Cha 2008; McDowell \& Batten 2005; Oyedeji 2007, 116; Siegert, Gerth \& Rademacher 2011, 65).

In the face of competition, strategic media management identifies media branding as a dynamic antidote to the need for media outlets to be ear and eye-catching to audiences to stay relevant and also survive (Chan- 
Olmsted 2011; Malmelin \& Moisander 2014; Ots 2008). While providing the needed orientation for media audiences to make choices (Siegert, Gerth \& Rademacher 2011, 65), branding affords media firms with a viable strategy to "focus on points of differentiation that offer sustainable competitive advantage" (Ghodeswar 2008, 4) over the products of competitors. Some benefits of media branding include improved perception of product performance; greater customer loyalty, less vulnerability to competitive marketing actions and marketing crisis; increasing marketing communication effectiveness; and additional licensing and brand extension opportunities (Hoeffler and Keller 2003; Keller 2009).

The above benefits notwithstanding, media branding presents critical decision-making on the part of media managers regarding the market and journalistic orientations to follow, and this is often evident in the kind of gatekeeping they engage in. While these two orientations have been found to be in contention, the ability to draw a balance between them, or whichever has a stronger influence on the media outlet dictates the media brand identity projected to media audiences (Siegert, Gerth \& Rademacher 2011). Journalistic orientations are deeply dependent on "standards of professional ethics, normative guiding principles of journalism, and the ordinary amount of background investigation behind a story" (Siegert, Gerth \& Rademacher 2011, 58). On the other hand, the market orientations considers the "price-performance ratio or, more implicitly, the amount of budget available; the intensity of financial control; and the structure of financing from sales" (Siegert, Gerth \& Rademacher 2011, 11). These two orientations function hand-in-hand, in that, inasmuch as news organisations need to educate, inform and entertain audiences, there is also a need to ensure viability. Research has shown that media organisations with strong financial grounding often engage in journalistic orientations based on the social and advocacy stories they publish. When the finances of the media organisation is not strong, however, they are compelled to engage in paid stories or every means to increase their finances, thus endangering the journalistic orientations of the organization (Entman 2005; McDowell 2011; Siegert, Gerth \& Rademacher 2011). Traditional media and their online digital brand extensions often do not have cause to think about survival because of their established parent brands which tend to support them financially, thus, the critical and journalistic-driven gatekeeping they engage in (Siegert, Gerth \& Rademacher 2011). Entman (2005, 58) asserts that traditional media pursue two central objectives which they are able to balance in the production of their news. The first is "reporting on important events, people and issues, particularly those involving governmental institutions and actors, in ways that are accurate and balanced." This main function is accurately undertaken by traditional media because they often have the structure and resources to do that well. The other objective is that of "generating sufficient advertising and circulation revenue to make profit regarded by the stock market or private owners as acceptable."

On the other hand, solely online digital brands without traditional media affiliation have been conceptualised to often engage in paid stories, public relations information and commercially-driven gatekeeping to survive (Siegert, Gerth \& Rademacher 2011). Due largely to the need to survive, they put their financial interests, often, before the information needs of their audiences and engage in stories and gatekeeping activities that will increase their returns on investments. Such media organisations are described as self-regarding trustees (Coleman 1990; Przepirorka \& Berger 2017) of information. Though information is abundantly available, they engage in gatekeeping that ensures that the benefits retained on making information available audiences is high.

McDowell $(2011,48)$ has observed that few media organisations have huge profits, but the more established ones have greater advantage of survival because they remain favourites for selection by audiences over smaller news organisations. Additionally, the longer audiences stayed on online news platforms, the more the financial inflows and the more other businesses advertised with them. A study by the Pew Research Centre (2010b) found that most online news users claimed not to have a favourite news outlet and so shuffled between news sites, but of the few that indicated their preferences, online news outlets of major news organisations topped the list of favourites. Similar findings had previously been observed by the Nielsen Media Research (2009) showing the great deal of effort that solely online news media organisations need to put in to be accepted by audiences.

Media branding is directly associated with gatekeeping because the branding orientation adopted determines the kind of stories and gatekeeping to engage in, that is, stories to publish, follow-up etc. For the purpose of this study, gatekeeping will be defined by adapting various definitions to mean the process of selecting, writing, editing, positioning, scheduling, repeating, and otherwise massaging information to become news (Donohue, Tichenor \& Olien 1972, 43; Shoemaker, Johnson, Seo \& Wang 2010; Shoemaker, Vos \& Reese 2008 124). This means that whatever activity is performed on a piece of information in the process of it becoming news can be described as part of the gatekeeping process.

Gatekeeping may often be applied differently by various media stakeholders. It is often applied depending on the branding strategy adopted by media institutions, although the intention of making information available to others may be the same. Public, citizens and online-users publish what they deem as newsworthy and informational to their intended audiences, though this may not follow any professional or normative gatekeeping process. This could be information they create themselves, information adapted from other sources for sharing or those they wholesomely adopt from other sources and redistribute to their audiences. Public, citizens and online- 
users as used in this context refers to ordinary citizen or netizen internet users. For media practitioners, on the other hand, gatekeeping may follow acceptable professional and normative procedures to ensure objectivity, fairness and balance. However, the intended brand identity to be portrayed to the audiences and the general public dictates the delicate and detailed gatekeeping decisions and activities to be undertaken (Siegert, Gerth \& Rademacher 2011). Through gatekeeping activities, media organisations are able to position media brands in the minds of their audiences so that competition from the digital media space does not impact negatively on their brand personality (Tungate 2005).

\section{Objectives}

Against the backdrop of the literature review, this study aimed at answering the following research questions:

1. What gatekeeping strategies do solely online digital news organisations in Ghana engage in?

2. What characterizes the gatekeeping strategy adopted by solely online digital news organisations in Ghana?

3. How does the type of gatekeeping engaged in by solely online digital news organisations impact their relevance and survival in the digital media space in Ghana?

\section{Theoretical framework - Media, Brands, Actors and Communication (MBAC) model, Siegert, Gerth and Rademacher (2011)}

The Media, Brands, Actors and Communication (MBAC) model is a framework that provides explanation for "the behaviour of media companies and the performance that results from their media content" (Siegert, Gerth \& Rademacher, 2011 57). With this model, it is argued that to ensure their survival, media organisations are to approach their news coverage in a quality-oriented manner by including quality as part of their brand identity building activities and this will attract the right caliber of audiences to ensure their sustainability. It unearths how media brand identity could serve as a decision making tool for designing brand and journalistic contents through gatekeeping. Aside the structure-conduct-performance market drivers (political, social, regulative and technological environment), media brand managers make decisions on the brand identity to be projected by the media house by drawing a balance between editorial decisions/journalistic orientation and the management decisions/market orientations. By the orientation favoured, the media brand position is determined by the quantity and quality of news coverage and this in turn defines the media brand image and media brand reputation to be communicated to and observed by media audiences and the general public. These decisions subsequently impact the major and delicate gatekeeping strategies and decisions that news media organisations would uphold in terms of target audience to reach; the types of news stories to select, publish and follow up; image selection; language choice and writing style in journalistic content production; and even the way their anchors present themselves in hosting programmes. In all these, cognizance is given to influencers of media content including citizens and consumers; PR and advertising agencies; as well as sources, owners and investors.

By deliberate brand decision-making and effort, "quality can still be a choice" (Siegert, Gerth \& Rademacher 2011, 55), on the premise that "media companies continually [choose to] produce news coverage of good quality only when such an orientation is part of their media brand identity" (Siegert, Gerth \& Rademacher 2011, 55). This thus calls for purposeful effort through institutional arrangements to put gatekeeping and editorial policies in place to achieve quality journalism through branding because "successful media brands are not only tools for marketing communications, but lead to brand culture and brand behavior within an organisation" (Siegert 2015, 360). Aside their brand names, slogans or logos, media outlets can make conscious effort to build brand identities to be perceived by their audiences as sources of quality and credible news, and engage with their audiences on that principle.

\section{Methodology}

\subsection{Research Design}

The study is an exploratory qualitative study, contributing to the literature and debate of the relevance of gatekeeping in the digital era. It follows an interpretive research paradigm (Bagele \& Kawulich 2012, 9; Scotland 2012,11), drawing on research methodologies, philosophies, ideologies and epistemologies of finding meaning to how online news media outlets go about their gatekeeping and how it impacts their survival. Since interpretive research renders itself useful in using issues, language and research approaches that empower the participants, recognizes the silenced voices, honour their individual differences and position the researcher and participants' views in a historical, personal or political context (Deem 2002), semi-structured interviews were used as data collection tools from the online news editors, social media managers and social media curators of three purposively sampled online news media outlets that are hosted in Ghana.

\subsection{Sampling Strategy and Data Source}

This study purposively sampled three online news portals in Ghana. These were modernghana.com, 
mynewsghana.net and newsghana24.com. These were sampled based on the type of news they publish which is general news (education, politics, business, entertainment, sports, etc). Other defining criteria for selection was the fact that they are hosted in Ghana, they have social media accounts including Twitter, they have over 1,000 followers on Twitter and have operated for over one year.

The study employed semi-structured interviews, which is a primary data source. Semi-structured interviews are a "wide-ranging category of interview in which the interviewer commences with a set of interview themes but is prepared to vary the order in which questions are asked and to ask new questions in the context of the research" (Saunders et al. 2009b, 601). The research objectives and questions set the basis to carve the interview questions and to prepare the interviews schedules. Different sets of interviews guides were prepared for the online news editors, social media curators and social media managers of each of the news organizations. Though nine semi-structured interviews were expected only six were undertaken because aside mynewsghana.net which had all three staff in place, newsghana24.com had only an Online News Editor and Modernghana.com did not have a social media curator at the time of the study. Though the sample size was small, the information power of these professionals was the major defining criteria for their selection for the study and also the fact that their specialized job descriptions placed them in peculiar position to meet the research objectives set for this study. In accessing the study areas, permission letters were sent to each news organization, which were approved before the study begun. Each interviewee was made to complete and informed consent form, and each interview session was recorded with the permission of the interviewees. All interview recordings were transcribed and the transcripts sent to the interviews for confirmation, member checking and to establish factual accuracy.

\subsection{Data Analysis Method}

The data analysis method adopted in this study was the thematic analysis to manage and make sense of the unwieldy interview data, by generating themes and sub-themes for the findings and discussions. Thematic analysis is a form of pattern recognition within data, which makes use of emerging themes as categories for analysis through careful reading and re-reading of the data (Fereday \& Muir-Cochrane 2006, 82; Bowen 2009, 32) to familiarise with the contents and to help generate initial themes (Saunders et al. 2009b, 491-492). In this study, data analysis was manually done by first inputting various responses from interviewees onto an Excel sheet and saving the file. This helped to categorise all the gathered data into manageable units. With the help of the filter menu, various themes were assigned to each category of information. On the basis of the detailed information provided by the interviewees, sub-themes were assigned to the themes to capture every intricate detail. The data was engaged inductively to generate the themes and sub-themes, ensuring that no part was left unattended to. The data produced thirteen (13) themes which were merged into six (6) themes as discussed in the subsections that follow.

\section{Findings and discussions}

Media organisations, according to the ethics of the profession are expected to be professional and objective in their reporting. However, sustainability of small media organisations often do not permit them to be as objective as they have to be especially in writing and publishing critical and hard news stories. Because of this most of them resort to soft news like entertainment and sports, which does not require them to be very critical. In the case when they have to report on critical and hard news stories, they often source it from traditional media outlets and credit those channels. Fosu (2010) has noted that sustainability of the media business in Ghana is an issue that needs urgent attention because it affects remuneration of media professionals and this could have negative impact on press freedom and ethical standards. This has also been accentuated by Ziem (2013).

Solely online news portals in Ghana, like most developing countries, are small in nature and as such under resourced in terms of human and financial capital. The main sources of income for them include advertisement, publishing paid stories like public relations information and their ability to engage the attention of their audiences to stay longer on their online platforms. This is often not enough to sustain the activities of a media organization, making media practice in Ghana not lucrative and rewarding, affecting the caliber of staff employed whose salaries are very low, compelling practitioners to take up other professions (Ziem 2013; Daabu 2011; Fosu 2010).

The major objective of this study was to find out the gatekeeping strategies adopted by solely online news portals in Ghana and how this impacted their competitiveness and survival. Generally, gatekeeping may have a universal understanding or implication of preparing stories about events into news. However, for solely online digital news portals in Ghana, gatekeeping has been found to be synonymous to sustenance or survival. This is because actors in the gatekeeping process in these organisations often have the financial implications of their activities on the news organsations underlying their choices and decisions. This assertion is elaborated by the findings and discussions that follow in the subsequent sections and sub-sections. 


\subsection{Heavy patronage of social media to route traffic to website}

The priority of solely online news portals in Ghana is to attract audiences to their website and to generate the much needed traffic. This is because the more traffic they generate on their website, the larger their cash-inflows and the greater their chances of attracting advertisements from marketers. Due of this, aside getting audiences directly on their websites, online news portals largely use their social media handles, especially, Twitter to route traffic to their websites. Twitter allows for only 280 characters of information on its interface and so online news portals use it as a teaser to carry their news headlines and story links to the website. The success of Twitter in aiding news outlets to route traffic to their websites has made it the most news-oriented or "newsful" social media platform (Chyi \& Chadha 2011, 437; Graham 2008). It is evident that solely online news portals in Ghana largely use social media to their advantage owing to the fact that they want to employ every means to make their website visible because that is the main news outlet they have. One online news editor revealed that for his news organisation, "the first aim is to attract people to come and read on the website so we connect them through social media." This makes their social media handles important sources for routing audiences and so they keep a number of social media handles, manage and maintain a good rapport and engagement with their audiences on them.

6.2 Catchy and sensational framing of headlines to attract audiences to the website to generate traffic

One observation about the kind of headlines framed by solely online news portals is that, they were often found to be attention-drawing headlines which sometimes end up being described as sensational. Beyond that, some were found to be click-baits (Blom \& Hansen 2015) which were difficult to connect or draw a linkage between them and the stories they referred to. It was observed through the interviews that one aim for the kind of headlines that solely online news organisations frame was to get audiences to visit their websites on every count possible. This was found to add-up to their monetary reward since it routes people to the website and the longer they stayed trying to draw connection between the headline and the story, the greater the financial inflows and monetary benefits for the online news portal.

During the semi-structured interviews, it was revealed that sometimes, the same story is given different catchy headlines or is written from various angles or twists to make it seem different. This creates an illusion of different stories in the minds of audiences, to get them to read all the versions of the same story. This keeps audiences longer on the website of news outlets for the attendant benefit. The following extract from the interviews transcript is evident:

- When we give different titles to the various contents we share on different platforms, it provides variety. It is possible that someone is following you on Twitter and has read that content and seen the link alright with an image. When the person goes to say Facebook, he may see a different inscription for the same story. The person may read it again but if it is the same headline and content, the person may ignore it. But the different inscription may make the person feel like it is new and they will open it to read. We sometimes do this integrated marketing strategies just to ensure that though we are sharing different information, they all arrive at the same web page so that we generate the needed traffic.

\subsection{Engaging all forms of data-marketing and search engine optimization tools to increase visibility of news stories}

Visibility of news stories of solely online news portals by audiences is key. This is because, in completing the news cycle, the last step before feedback is for the intended audiences to receive the news. Solely online news portals in Ghana were observed to use all available and known methods to make their news visible to their audiences. Some undertake courses in avenues that will help increase the visibility of their news stories. The following information speaks to that:

- I am working for an online news portal, nobody will know your presence online until you share your news so I went to learn about data marketing, where I was given training on how to market my online content on Whatsapp, Facebook, Twitter, Instagram and all the other news channels, how to make people register on the website and receive news updates so that when you publish a story online, they are able to have access to it. I now apply that in my operations. Also, you know when you publish content, it does not go anywhere. It stays on the website until Google is able to recognise it so I went for another training called search engine optimization, so that when I publish the content, I can work behind the scene and then make Google to identify the content and make it available to people who search for it. This makes my work a little bit easier because, for instance, if I publish a content and I am able to use search engine optimisation to make it relevant and known to Google and Google indexes it, it means that even if I don't share it on social media, so far as people type keywords that are found in that document, there is a high chance that Google will show it to them so people will find my content on Google, Yahoo and 
other search engines because of the search engine optimisation which I have learnt and implement in the course of my work.

6.4 difficulty in publishing critical news due to influencers

Every news content is influenced in one way or another by the 'gates' it travels through on its way to becoming news. In White's (1950) seminal study of gatekeeping media content, he observed how 'Mr. Gates' made subjective decisions on what becomes news and what does not. Subsequent to that, other scholars (Shoemaker 1991; Shoemaker \& Reese 1996, 2014; Shoemaker \& Vos 2009) have broadened the context, projecting that, aside the individual editor, there are other influencers of news content that serve as "multiple forces that simultaneously impinge on the media and [also] suggest how influence at one level may interact with that at another" (Shoemaker \& Vos 2014, 1). This gatekeeping phenomenon which was observable in the golden age of media is still visible in the digital age, debunking the assertion that gatekeeping in the digital era is in a state of transition (Shoemaker \& Vos 2009; Vos \& Heinderyckx 2015).

For solely online news portals, it was found that their major influencers were mainly financiers or organisations that supported them, and so to avoid losing that support, critical stories that will impact negatively on their financiers were avoided. Not only that, but critical stories and hard news content like political news content required executive permission to publish to avoid defamation suits. This only leaves them with soft stories to publish but critical stories are sourced from other traditional media outlets and the source acknowledged. This assertion is evidenced below:

- Yes, that is why we cannot do those top-level articles without the top-level executives consent. You know, sometimes it's not political but...I quite remember there was a communication about a bank and a TV station that had dismissed their staff without any notice. I particularly had that article because a lady who was sacked sent me notice of their dismissal letter and all that. I drafted a publication that I was about publishing but unfortunately, I was told to bring it down because the bank in question had a partnership with our platform so we just had to bring the article down. So sometimes, those things also influence our stories.

- For the content that goes online, we have them in two sections. Due to legal issues, there are categories of news stories that can go online without actually going through any screening whatsoever, as long as it comes from a reporter that is working with us. And there are other categories of stories that cannot go online except a top-level executive has actually approved it, especially in the case of politics. If I find a news item like an accident or any happening in town that I think is news worthy, I can just go ahead and get it published directly onto the platform. But if I find a news article that I know this is a political issue and based on my experience I think this thing can actually go viral, I have to contact somebody at the top-level executive to approve of it before the story can go live. So there are two sections - more flexible articles like sports and entertainment can go freely but political issues and related issues cannot go like that.

6.5 Difficulty in attracting advertisements due to limited traffic inflows to their websites

Advertisements remain undoubtedly one of the major income sources available to media organisations. Unlike most online digital brand extensions of traditional media in Ghana that attract advertisement from major businesses due to the huge audience traffic daily, the situation of solely online news portals is different. Most of them are still in the process of working to improve on their reputation and acceptance by audiences. In spite of their years of existence, most of them still have a long way to go as far as reaching the level of acceptable audiences traffic which can attract advertisements to them is concerned. This confirms their use of all manner of gatekeeping strategies to improve their financial inflows and the survival of their news organisations. The following excerpt from the semi-structured interview transcripts give credence to this finding:

- For now, we do not have adverts coming in. There is one thing about getting advertisements from businesses. What they look out for is that your brand should have super traffic. Brands that very often get advertisements coming in have not less than 100,000 visitors a day. Because, when businesses put their adverts there, they also expect the returns and so they will ask questions like "what is the minimum traffic you generate a day?" I have had opportunities like that from the US and UK and they ask questions like "so what is the traffic situation on your platform like?" For those people, the traffic they were expecting was like a minimum of 20,000 a day but our traffic hits like 15,000 a day or as low as 1000 on some days so you don't get volume in there. But even with that traffic, sometimes, I get friends and some smaller businesses who want to advertise their products or services on the website. And for them, it is just a token just to put them out there and give them that leverage for the mile they want to go so that others can also see what they are doing. 
6.6 Commercial, rather than journalistic brand identity building strategy

When interviewees were asked whether the stories they put up on their social media handles and their websites are for journalistic or commercial purposes, it was revealed that, though online news editors, news curators and social media managers had both journalistic and commercial intentions in mind, for the solely online news portals, the commercial purpose always superseded the journalistic purpose. This was because of their nature as small business enterprises, often with five or less staff. This inhibits and limits their news gathering and processing capacity. They sometimes depended on some traditional media or larger online news portals as sources of their news. With this as a basis, most of the news from their own sources are often commercially motivated to increase their financial inflows. The following information provide depth to this assertion:

- It is a combination of the two. There are stories we do for journalistic purposes... But there are content we put out there and we know that as for this content, it is going to draw in traffic which will be converted into financial inflows. And so it is both sides, however, for me, it is more tailored towards the earning. We don't lose sight of the fact that the journalistic aspect should also be revealed in the content we put out there. So it is both, but the financial aspect will very often over-ride the journalistic aspect. However, even if we are tilted towards the financial aspect, that should not lead to a lower content or just putting anything out there. It should be relevant to the times and needs of the readers. So for me, it is both but the financial will always outweigh the journalistic aspect.

- As a private and small business, the business must survive and grow. If it was a public institution, they will tilt more towards the journalistic aspect but for private media houses or online portals, the focus or emphasis is more on the financial aspect.

- We always consider something that will entice or interest our audiences to like, comment or react to whatever we have put up. It's a fact we consider but that is not the only thing. We also ensure that whatever we have put there is something that is of value to the person going to read it.

- It's 50/50. There are situations that you publish articles because those articles will increase financial inflows, not as in taking funds from people to favour them with publications but on a normal day, if we are to report and it has nothing to do with the money, you will report from head to toe without thinking about how to create a headline that will entice somebody because you know you are just submitting or publishing a report. But in this case, you need to submit your report, thinking of paragraphs that will even extend the content to make the reader stay longer on the website, for much revenue inflow. You have to make sure that the reader stays longer on that article and then you have to put in all the research that you have done. You need to have a very nice headline, you need to get a catchy image that you think when they see the image that comes with the article, they will be pushed to open. Sometimes, you have to go to the extent of looking for different images of the people involved in the article and merging them, making a graphic designer work on the pictures and all that, so we do those things with the intention of enticing the reader or making the reader stay longer on the site for more revenue inasmuch as we know we are reporting the particular article to them.

It has been argued that media organisations that put their interests before that of their audiences are selfregarding trustees (Coleman 1990; Przepirorka \& Berger 2017) of information meant to be put at the disposal of audiences. Such situations often brood a selfish ambition where news organisations are moved by their expected gain over the benefit of their programming to their audiences. In effect, the news content sent out by such media organisations are essentially commercial and public relations stories which are in the financial interest of the media organisation, with little or no relevance to media audiences. When audiences feel that their information needs are not being met by the media organization, further engagements or advances are unlikely (Coleman 1990; Connelly et al. 2011; Przepirorka \& Berger 2017, 375), and the media organisation may lose their audiences to other news outlets.

\section{Conclusion and recommendation}

The study interrogated the gatekeeping strategy of some solely online news media organisations in Ghana. From the discussions above, solely online news organisations in Ghana emerged with the digital era. They are small organisations in nature, but the competitive environment where they rub shoulders with established traditional media organisations burdens them with the need to survive. Their limited finances and income makes it imperative to follow a gatekeeping strategy that results in a largely marketing orientation because of their nature, the need to sustain their media organisations and also the need to employ and retain professionals in their organisations.

This paper recommends that, the issue of media financing and funding should be a critical aspect for consideration in licensing media firms to ensure that they are sustainable in order to maintain the dignity of the media profession in any democratic society such as Ghana. Additionally, it is recommended that, for solely online news organisations to reduce their operating costs, there is a need for them to partner with traditional or established media organisations and the Ghana News Agency for journalistic news information for publishing. 
They could also merge with other online news organsations within their category. Finally, instead of employing reporters, they could outsource their news reporting which will be financially less burdening than employing full-time reporters.

\section{References}

Aboagye Da-Costa, C., Ganaa, F. K. \& Apeakoran, E. N. (2021). Technological Determinism: new media adoptations and adaptations within traditional media in Ghana. The Information Technologist, 18(1),1-16.

Aikakauslehtien litto. (2005). [Finnish Periodical Publishers Association]. "Aikakauslhtien Liiton jäsenlehtien sähköiset palvelut 2005.” A report by Dynamo advertising (February 14, 2005)

Bagele, C. \& Kawulich, B. (2012). "Selecting a research approach: paradigm, methodology and methods."https://www.academia.edu/15804348/Selecting_a_research_approach_Paradigm_meth odology_and methods (September 29, 2020).

Boczkowski, P. J. \& De Santos, M. (2007). When more media equals less news: patterns of content homogenization in Argentina's leading print and online newspapers. Political Communication, 24 (2), 167180. Doi: $10.1080 / 10584600701313025$

Bosch, T. (2014). Social Media and Community Radio Journalism in South Africa. Digital Journalism, 2 (1), 29 43.

Bowen, G. A. (2009). Document analysis as a qualitative research method. Qualitative Research Journal, 9(2), 27-40.

Brandtzæg, P., Lüders, M., Spangenberg, J., Rath-Wiggins, L., \& Følstad, A. (2015). Emerging Journalistic Verification Practices Concerning Social Media. Journalism Practice, 10(3), 323-342. DOI: 10.1080/17512786.2015.1020331

Bruns, A. (2005). Gatewatching: collaborative online news production (digital formations). New York: Peter Lang.

Bruns, A. (2003). Gatewatching, not gatekeeping: Collaborative online news. Media International Australia Incorporating Culture and Policy: Quarterly Journal of Media Research and Resources, 107(1), 31-44.

Bruns, A. (n.d). "Gatekeeping, gatewatching, real-time feedback: the challenges for journalism." http://snurb.info/files/2011/Gatekeeping,\%20Gatewatching,\%20Real-Time\%20Feedback.pdf (December 12, 2019)

Bullard, S. B. (2013). "Social media and journalism: what works best and why it matters." A paper presented at the National Convention of the Association for Education in Journalism and Mass Communication Conference. Washington DC, Aug 10.

Daabu, M. A. (2011). "Salaries of journalists disgraceful - Kwame Pianim." https://www.modernghana.com/news/317439/salaries-of-journalists-disgraceful-kwame-pianim.html (November 28, 2017).

Chan-Olmsted, S. (2011). Media branding in a changing world: challenges and opportunities 2.0. International Journal on Media Management, 13(1), 3-19.

Chan-Olmsted, S. M \& Cha, J. (2008). Exploring the antecedents and effects of brand images for television news: an application of brand personality construct in a multichannel news environment. The International Journal on Media Management, 10, 32-45.

Chyi, H.I. \& Chadha, M. (2011). News on New Devices: Is Multi-platform News Consumption a Reality? Journalism Practice 6(4), 431-449. Doi:10.1080/17512786.2011. 629125.

Coleman, J. S. 1990. "Foundations of social theory." Cambridge (MA): The Belknap of Harvard University Press.

Donohue, G. A., Tichenor, P. J., \& Olien, C. N. (1972). Gatekeeping: Mass media systems and information control, in FG Kline \& PJ Tichenor (Eds.) "Current perspectives in mass communication research.” Beverly Hills, CA: Sage: 41-70.

Ellonen, H-K. (2007). "Exploring the strategic impact of technological change - Studies on the role of internet in magazine publishing." Doctoral thesis. Lappeenranta University of Technology. Acta Universitatis Lappeenrantaensis, 261.

Entman, R. M. (2005). "The nature and sources of news.” In G. Overholser (Ed.), Institutions of American democracy series, pp.48-65. The press. New York: Oxford University Press.

Fereday, J. \& Muir-Cochrane, E. (2006). Demonstrating rigor using thematic analysis: a hybrid approach of inductive and deductive coding and theme development. International Journal of Qualitative Methods 5(1):80-92. http://journals.sagepub.com/doi/pdf/10.1177/160940690600500107 (March 14, 2019)

Fosu, A. 2010. "Poor remuneration for Ghana's journalists- a bane to press freedom and ethical standards." https://www.ghanabusinessnews.com/2010/08/31/poor-remuneration-for-ghanas-journalists-a-bane-topress-freedom-and-ethical-standards/ (November 27, 2017).

Graham, J. 2008. "Twitter took off from simple to 'tweet' success." USATODAY.com, July 21. 
http://www.usatoday.com/tech/products/2008-07-20-twitter-tweet-social-network_N.htm (January 5, 2019)

Heinderyckx, F. \& Vos, T. (2016). Reformed gatekeeping. Communication and Media XI(36), 29-46.

Küng, L. (2008). "Strategic Management in the media: theory to practice." London: Sage.

McDowell, W. S. 2011. The brand management crisis facing the business of journalism. International Journal on Media Management, 13(1), 37-51.

McDowell, W. (2006a). Confrontation or conciliation: the plight of small media brands in a zero sum marketplace. Journal of Media Business Studies, 3(2), 1-22.

McDowell, W. (2006b). Issues in marketing and branding, in AB Albarran, SM Chan-Olmsted \& MO Wirth (Eds.), "Handbook of media management and economics." Nahwah, NJ: Lawrence Erlbaum.

McDowell, W. S \& Batten, A. (2005). "Branding TV: Principles and practices.” Burlington, MA: Focal.

McDowell, W. S. (2004). Exploring a free association methodology to capture and differentiate abstract media brand associations: a study of three cable news networks. Journal of Media Economics, 17, 309-320.

Nielsen, R. K. (2014). "Varieties of online gatekeeping. Rethinking Journalism II: The societal role \& relevance of Journalism in a digital age." University of Groingen, Netherlands. Available at SSRN 2675055.

Nielsen Media Research. (2009). "Global faces and networked faces: A Nielsen report on Social Networking's New Global Footprint." https:/www.nielsen.com/wp-content/uploads/sites/3/2019/04/Global-Faces-andNetworked-Places-A-Nielsen-Report-on-Social-Networkings-New-Global-Footprint.pdf

Oyedeji, T. A. (2007). The relation between the customer-based brand equity of media outlets and their media channel credibility: an exploratory study. The International Journal on Media Management, 9(3), 116-125. Doi: 10.1080/14241270701521725.

Pew Research Centre. (2010). "Pew Internet and American life project study. Understanding the participatory news consumer." Project for Excellence in Journalism. Washington, DC.

Phillips, A. (2015). Low-paid piecework or global brands?, in "Gatekeeping in transition," TP Vos \& F Heinderycks (Eds.). New York: Routledge: 65-81.

Przepiorka, W. \& Berger, J. (2017). Signalling theory evolving: signals and signs of trustworthiness in social exchange, in "Social dilemmas, institutions and the evolution of cooperation," J Ben \& W. Przepiorka (Eds.). Berlin: Walter de Gruyter GmbH, 373-392.

Russ-Mohl, S. \& Nazhdiminova, R. (2015). Media branding and media marketing: conflicts with journalistic norms, risk of trial and error. In "Handbook of media branding," G. Siegert, K. Förester, SM Chan-Olmsted, \& M. Ots (Eds.). Switzerland: Springer, 337-353.

Saunders, M., Lewis, P. \& Thornhill, A. (2009b). "Research methods for business students." $5^{\text {th }}$ edition. England: Pearson.

Scotland, J. (2012). Exploring the philosophical underpinnings of research: Relating ontology and epistemology to the methodology and methods of the scientific, interpretive, and critical research paradigms. English Language Teaching, 5(9), 9-16.

Shoemaker, P. J., Johnson, P. R., Seo, H. \& Wang, X. (2010). Readers as gatekeepers of online news. Brazilian Journalism Research, 6(1), 55-77.

Shoemaker, P.J., \& Vos, T. (2009). "Gatekeeping theory.” Routledge.

Shoemaker, P. J., Vos, T. P. \& Reese, S. D. (2008). Journalists as gatekeepers, in "The handbook of journalism studies," edited by K Wahl-Jorgensen \& T Hanitzsch. New York, NY, Routledge, 73-87.

Shoemaker, P. (1991). "Gatekeeping.” Newbury Park, CA: Sage.

Shoemaker, P. J. \& Reese, S. D. (1996). "Mediating the news: theories on influence on mass media content." White Plains, NY: Longman.

Siegert, G. 2015. Market driven media brands: supporting or faking high journalistc quality?, in "Handbook of media branding." G Siegert, K Förster, SM Chan-Olmsted and M Ots (Eds.). Switzerland: Springer, 281293.

Siegert, G. Gerth \& Rademacher. (2011). Brand identity-driven decision making by journalists and media managers - the MBAC Model as a theoretical framework. International Journal on Media Management, 13(1), 53-70.

Tarkiainen, A., Ellonenm, H.-K., Kuivalainen, O., Horppu, M. \& Wolff, E.-E. 2008. Magazine online brand extensions: do they really affect brand loyalty?, in "Media Brands and Branding," M Ots (Ed.), 53-77. Jönköping, Sweden: JIBS Research Reports.

Tungate, M. (2005). "Media monoliths. How great media brands thrive and survive.” London: Kogan Page.

Welbers, K. \& Opgenhaffen, M. (2018). Social media gatekeeping: an analysis of the gatekeeping influence on newspapers' public Facebook pages. New Media \& Society, 20(12), 4728-4747.

White, DM. (1950). The “Gate Keeper": A Case Study in the Selection of News. Journalism Quarterly, 27(3), 383-390.

Ziem, J. (2013). "Poor remuneration affecting journalism standards." https://www.ghanaweb.com/GhanaHomePage/NewsArchive/Poor-Remuneration-Affecting-Journalism- 
Standards-271598 (November 27, 2017).

Caroline Aboagye Da-Costa is a Research Development Officer at the Ghana Institute of Journalism. She is a doctoral candidate of the University of South Africa, with specialization in media brand management and competitive strategies. She obtained her first degree in Publishing Studies from the Kwame Nkrumah University of Science and Technology (KNUST) in 2005, graduating with a First Class Honours. She later furthered with a researched Master of Arts in Communication Science from the University of South Africa, where she graduate in 2019 with Distinction. Mrs. Aboagye Da-Costa has thirteen years of experience as a University Administrator (2007-2019), having worked at the department and faculty levels as well as the School of Graduate Studies and Research. Her areas of research interest include: Broadcast Journalism, Media and Languages; Media Regulation; Media Brand Management and Competitive Strategies as well as Media and Sustainability Development issues.

Eric Opoku-Mensah is an Associate Professor of Communication and the Deputy Rector of the Ghana Institute of Journalism.

Daniel Machator is an Assistant Registrar, Public Affairs at the Ghana Institute of Journalism, a writer and columnist in the area of security. He has rich communication experience. Mr. Machator holds a Master of Arts in Communication Degree from the University of Cape Coast and a Bachelor of Arts Degree in History with Linguistics from the University of Ghana. He also holds certificates in Countering Violent Extremism in Public Places, Conflict Resolution in Detention Centres, and other security-related courses. Prior to his appointment at the Institute, Mr. Machator was the Deputy Chief Public Relations Officer for the Ghana Prisons Service. As the deputy national spokesperson for the Prisons Service, he in concert with the Chief Public Relations Officer, developed, managed, and defined the tone of the service's communication materials for the attention of media houses. He was additionally responsible for the development of strategic partnerships with key stakeholders of the service among other public relations functions.

Mr. Machator had earlier served as the Central Regional Public Relations Officer for the Ghana Prisons Service, a position he held for seven years. Before his enlistment into the senior corps of the Ghana Prisons Service, Mr. Machator worked with Theovision International as Radio Station Manager for Radio Gaakii in Saboba, Northern Ghana. An accomplished correctional manager, writer, speaker and award-winning columnist, Mr Machator has a great interest in youth development and correctional reforms. He is a Member of the Institute of Public Relations, Ghana. 